\title{
The Completion of Misdemeanor through Rembuk Pekon in Lampung Province
}

\section{Zulfi Diane Zaini ${ }^{1}$, Lintje Anna Marpaung ${ }^{2}$, Zainab Ompu Jainah ${ }^{3}$, Thia Remona Febrianti ${ }^{4}$, Sija Putra Rulanda ${ }^{5}$}

\author{
${ }^{1}$ Universitas Bandar Lampung, Indonesia, Email: zdiane.zaini@yahoo.com \\ ${ }^{2}$ Universitas Bandar Lampung, Indonesia, Email: lintjeam@yahoo.com \\ ${ }^{3}$ Universitas Bandar Lampung, Indonesia, Email: zainab@ubl.ac.id \\ ${ }^{4}$ Universitas Bandar Lampung, Indonesia, Email: thiaremona1994@gmail.com \\ ${ }^{5}$ Universitas Bandar Lampung, Indonesia, Email: sija.putrarulanda.sp@gmail.com
}

Article Info

Keywords:

Alternative Dispute Resolution, Rembuk Pekon, Light Criminal Acts, Restorative Justice

How to cite:

Zulfi Diane Zaini, Lintje Anna Marpaung, Zainab Ompu Jainah,

Thia Remona Febrianti, Sija Putra

Rulanda, "The Completion of

Misdemeanor through

RembukPekon in Lampung

Province, " Fiat Justisia: Jurnal

Ilmu Hukum14, 2 (2020): 159-176.

DOI:

10.25041/fiatjustisia.v14no2.1880
The resolution of a criminal offence does not have to be carried out through legal channels. Still, it can be done in the spirit of restorative justice, one of which uses the principle of ADR (Alternative Dispute Resolution) or (win-win solution) through the Rembuk Pekon which means through consensus agreement. This study aims to determine what crimes can be resolved with the Pekon consultation, how the process is resolved, and what the legal consequences are. This study uses an empirical normative method by examining the methods, norms, rules and primary data through observation and interviews, the results of the study indicate that the types of criminal acts that can be resolved with Rembuk Pekon include minor criminal offences Article 302, Article 352 paragraph (1), Article 364, Article 373, Article 379, Article 482, Article 315, Article 407 paragraph 1, and the criminal offence of complaint Article 284 of the Criminal Code. So in this study will discuss how the process of resolving minor criminal cases through the Rembuk Pekon and the authors have a suggestion that the police should implement the Rembuk Pekon to prioritize the principles of professional, modern and reliable, this so that the implementation of the Rembuk Pekon can run optimally. 


\section{A. Introduction}

Criminal acts and crimes are part of the law that has always been a hot topic to be discussed from time to time. The interest of criminal acts is because of the formulation of criminal acts and crimes often experience changes along with the pattern of community development based on the development of information and technology that includes all communities In the past, during the nomadic period, humans committed criminal acts. Their trials were sufficient with physical violence, but after humans lived in the age of stone and metal, criminal acts began to be known by using tools and entering the era of industrialization Criminal. ${ }^{1}$

Crime prevention through criminal law policies will be effective if crime prevention is not only intended to resolve a criminal case by imposing a crime on the offender. Settlement of cases with the spirit of restorative justice must be able to find a fair solution and win-win solution for both parties, both victims and perpetrators. To achieve the of equitable resolution of criminal cases, mediation efforts are needed. Mediation is generally known as an alternative form of dispute resolution in civil law, but in its development mediation can be carried out in criminal cases. Mediation can be used in several special categories of crimes, namely in the category of minor criminal offences. The application of mediation in settlement of criminal cases aims not only to extend a conflict between the perpetrator and the victim but helps law enforcement officials reduce the accumulation of case files. ${ }^{2}$

Settlement of legal issues through mediation is a win-win solution where the parties win and lose so that the dispute does not last long and protracted and can improve relations between the disputing parties, the benefits of resolving a dispute using mediation are numerous, including costs cheap, fast, satisfying the parties to the dispute because it is cooperative, preventing the accumulation of cases in the court, eliminating resentment, strengthening the relationship and can strengthen and maximize the function of the judiciary in the resolution of disputes in addition to the judicial process that is decided (adjudicative). ${ }^{3}$

The win-win solution settlement mechanism is called ADR (Alternative Dispute Resolution). According to the provisions of Article 1 point (10) of The Act Number 30 of 1999 concerning Arbitration and Alternative Dispute Resolution, what is meant by ADR is "institutions for dispute resolution or dissent through procedures agreed by the parties, namely settlement outside

\footnotetext{
${ }^{1}$ T. Prasetyo,A. H. Barkatullah, Politik Hukum Pidana - Kajian Kebijakan Kriminalisasi dan Dekriminalisasi (Jakarta: Pustaka Pelajar, 2005), 5.

2 Z. D.Zaini, "Lembaga Mediasi Perbankan Sebagai Alternatif Penyelesaian Sengketa Perbankan di Indonesia," Jurnal Keadilan Progresif 3, No. 1 (2012): 1-20.

${ }^{3}$ M. Ridwan, "Mediasi Penal Terhadap Perkara KDRT (Kekerasan Dalam Rumah Tangga)", (Jakarta: Yayasan Gema Yustisia Indonesia, 2010), 166.
} 
the court by means of consultation, negotiation, mediation, conciliation, or expert judgment".

One of the minor criminal cases or misdemeanour that often occurs in the community is the crime of theft. Theft is a criminal act aimed at one's property or assets. This type of crime often occurs during people's lives. Although this crime is not a criminal offence classified as a serious crime such as murder, it can cause unrest in the community, especially those who live or live in an environment where the theft occurred. According to Article 362 of the Criminal Code, whoever takes something, which is wholly or partly owned by someone else, to be owned illegally is theft, with a maximum imprisonment of five years or a maximum fine of nine hundred rupiahs.

Further related criminal of theft in the Penal set in Article 364 that is more outlined that acts described in Article 362 and Article 363 point 4, so any actions described in Article 363 paragraph 5, if not done in a house or yard closed existing home if the price of the stolen goods is not more than 25.000 IDR, threatened for mild theft with imprisonment of three months or a maximum fine of two hundred and fifty rupiahs.

One of the theft cases that occurred was a handphone thief that occurred on July 17, 2018, at 17:15 West Indonesia time. There was an alleged handphone theft at Pahoman Stadium, Pahoman Village, Tanjung Karang Barat District, and Bandar Lampung City. The perpetrators stole the victim's phone while the victim was jogging. After successfully stealing the mobile phone from the victim's purse, the suspect fled out of the stadium. However, residents and managers of the stadium figured it out and took the thief under security. Regarding this case, police made efforts on Pekon consultation, considering the victim's mobile phone valued approximately1.000.000 IDR.

Related to this legal phenomenon, the Supreme Court initiated the issuance of the Republic of Indonesia Supreme Court Regulation Number 02 of 2012 concerning Adjustment of Limits of Minor Crimes and the Number of Fines in the Criminal Code. Based on these regulations, the Supreme Court sets limits on minor criminal offences and fines that can be imposed on minor criminal offences. Regarding fines that can be imposed outlined in Article 1 which outlines that the words "two hundred and fifty rupiahs" in Articles 364, $373,379,384,407$ and Article 482 of the Criminal Code read as 2.500,000.00 IDR (two million and five hundred thousand (Indonesian) rupiah)".

Indonesian National Police is a law enforcement agency that is directly responsible under the President. Based on Article 2 of The Act Number 2 of 2002 concerning the National Police of the Republic of Indonesia, the function of the Indonesian police is one of the functions of the Government of the State in the field of protection, protection and service to the public.

Further related on mediation in solving the crime, the Indonesian National Police issued a Regulation of the Police of Republic Indonesia Number 3 of 2015 on Community police stipulated in Article 1 point 2 which 
reads understanding of Community police is an activity to engage the community through a partnership member Indonesian National Police and the community, so as to detect and identify public Order and Safety issues in the ward and find a solution. In the regulation in Province of Lampung, the term Rembuk Pekon is familiar. Rembuk Pekon is local wisdom used by the Regional Government of Lampung and law enforcement agencies such as the Police is one of the efforts for settling disputes amicably to prevent the occurrence of vigilante actions of both warring sides. Rembuk Pekon which is a local wisdom Lampung where the program prefers preventive measures rather than repressive. Not only that, Rembuk Pekon program, which is the local knowledge, was also once changed the old paradigm of the success of the police. If the first success of the authorities in view of the number of misdemeanour offenders are prosecuted as a criminal has changed now that paradigm emphasizes deliberation.

One of the cases of Theft that occurred was petty theft, namely. The purpose of this study is eager to see and describe how the process of settlement of the offences that occur in the community by way of consultation pekon as one form of implementation of the noble values of Pancasila on four precepts which reads democracy led by the wisdom in the wisdom of representative deliberation. So in this study will write about how the process of resolving misdemeanour with Rembuk Pekon.

This study will use a type of normative research empirically, the research devoted to reviewing the application of the rules or norms of positive law applicable to experiences that occur in the community, as well as in the enforcement process using secondary data and primary data which obtained from the process of observation and interview. ${ }^{4}$ This is normative research, and the approach uses legis positivist conception. ${ }^{5}$ The concept looked identical legal norms made written and enacted by institutions or authorities. The conception of view the law as a normative system is independent, introverted and detached from the real-life of society. This study uses the approach of law (statute approach) this is done by examining all laws and regulations related to the legal issues are being addressed, and the approach

\footnotetext{
${ }^{4}$ H. Thalib, A. Ramadhan, H. Djanggih, "The Corruption Investigation In The Regional Police of Riau Island Indonesia," Rechtsidee 4, No. 1 (2017): 7186.https://doi.org/10.21070/jihr.v4i1.988.

${ }^{5}$ S. Soekanto,Sri Mamudji, Penelitian Hukum Normatif, Suatu Tinjauan Singkat (Jakarta: Raja Grafindo Persada, 2011), 12.
} 
case (case aproach). ${ }^{6}$ Law approach is used to determine the overall rule of law. ${ }^{7}$

\section{B. Discussion}

Pekon consultation which is a traditional policy in Lampung where the program prefers preventive measures rather than repressive. Not only that, Pekon consultation program, which is the local knowledge, was also once changed the old paradigm of the success of the police. If the first success of the authorities in view of the number of misdemeanour offenders are prosecuted as a criminal has changed now that paradigm emphasizes deliberation.

Therefore, legal or regulatory function to change the mindset of people to be law-abiding this case in accordance with the publication of some of the legislation on Rembuk Pekon among which the Provincial Regulation Lampung Number. 1 of 2016 on Guidelines for consultation villages and villages in Preventing Conflict in Lampung and also Regulation police chief Republic of Indonesia Number 3 of 2015 on community police, based on this it can be seen that the procedures for the settlement of the crime of theft through Rembuk Pekon done in several stages such as Nothing the reports/complaints from the public, coming to the crime scene, requesting information to victims, witnesses and other related parties of cases occurred, preparing for Rembuk Pekon, Conducting Rembuk Pekon, mediation process, giving advice and solutions, reaching closure followed with an agreement from both parties. Pekon consultation in the implementation of the police, in this case, members Bhayangkaya public order and safety supervisors should implement Rembuk Pekon to put forward the principle of a professional, modern and reliable, it is that the implementation of the Rembuk Pekon optimally. The need for an increase in efforts to settle the offence by the Rembuk Pekon process as local culture and local policy by the government, law enforcement officers and the public to achieve justice and reduce conflict in society, as well as increased cooperation between police and government officials Lampung province, to uncover other cases to be solved correctly and by procedures and can enhance guidance to the public the importance of knowledge of the law.

${ }^{6}$ N.Okamahendra, "Eksistensi Peraturan Mahkamah Agung No. 02 Tahun 2012 tentang Penyesuaian Batasan Tindak Pidana Ringan dan Jumlah Denda dalam KUHP," JATISWARA Jurnal Ilmu Hukum 32, No. 1 (2017): 110-119.https://doi.org/10.29303/jatiswara.v32i1.74.

7 B. Suhariyanto, "Progresivitas Putusan Pemidanaan Terhadap Pelaku Tindak Pidana Korupsi," Jurnal Penelitian De Jure 16, No. 2 (2016): 201-213. http://dx.doi.org/10.30641/dejure.2016.V16.201-213. 


\section{The Types of Crime can be Solved through Rembuk Pekon.}

Indonesian positive law in the criminal case cannot be settled out of the court but in certain things, possible implementation. In practice, there are several types of a criminal case could be resolved outside the criminal justice system process, including through the discretion of law enforcement officers, peace mechanism and traditional institutions, and so on. Actually, in Indonesian society, settlement of both civil and criminal cases with a peace mechanism or mediation through traditional institutions is not new; the completion of the consultation approach evidence this. When viewed in historical culture, it upholds the Indonesian people who prefer a consensus approach to decision-making which are traditionally or a settlement through traditional mechanisms.

As known, this community is already familiar with the peaceful dispute settlement, such as an event deliberation and also different types of events settlement through traditional entities taken by the prevalence of certain customary laws and practices as traditional law. Events indigenous settlement in Indonesia can vary in shape according to the context of the local situation. This situation is commonly known as the application of the principle of receptio in complexu, which apply customary law in it at once legal penetrate a religious belief or apply religious law applied at once as a rule of customary law. ${ }^{8}$

The Indonesian people have commonly known settlement issue with deliberation and consensus between the parties to the dispute for this. Even the term 'deliberation' was seen to contain personal philosophy typical of Indonesia, which is formulated into Pancasila as the most fundamental grounding in social life, nationality and statehood of the Republic of Indonesia.

One alternative solution is through mediation. Mediation is etymologically derived from the Latin, meaning Mediare in the middle. This meaning refers to the role of a third party as a mediator who has the task of mediating and resolving disputes with both parties. The mediator should be neutral and impartial in solving disputes. He should be able to keep the interest of the parties to the dispute fairly and equally, so grow the confidence of the parties to the dispute. ${ }^{9}$

The mediation process in normative it is known as the Settlement of Criminal Cases. Mediation is better known within the Civil Justice with the name ADR (Alternative Dispute Relation). However, in practice, this mediation process was a lot to do, and sometimes even mediation facilitated

\footnotetext{
${ }^{8}$ N. Simanjuntak, "Penguatan Lembaga Adat Sebagai Akternatif Penyelesaian Sengketa," Negara Hukum 4, No. 1 (2013): 36-66. https://doi.org/10.22212/jnh.v4i1.195.

9 F. A. Surya, "Tinjauan Mediasi Penal perspektif Hukum Adat dan Hukum Islam", Jurisprudence, 5 No. 2 (2015): 118-126. https://doi.org/10.23917/jurisprudence.v5i2.4229.
} 
by law enforcement officials. In the resolution of a criminal offence known as penal mediation, penal mediation itself is already known by some indigenous peoples are among the people of Papua, Aceh, Bali, Lombok, West Sumatra and Lampung community through a process called Rembuk Pekon. ${ }^{10}$

Therefore, the process of deliberation call with Rembuk Pekon in the process of solving problems in the community is still frequently used, namely in Lampung people still use pekon consultation solve the problems of crime that occurs in people who are still classified as misdemeanours. The crime itself divided into two, namely:

a. Crime

Crime is an act of deliberate (omission). In this sense, a person can be punished for his thoughts, but there must be an action or state in the act. Failure to act may also constitute a crime. If there is a legal shame to act in a particular case, in addition, there is malicious intent ("criminal insert", "mens rea") which is a violation of criminal law; Conducted without the presence of defence or justification legally recognized; Sanctioned by the state as a crime or offence. ${ }^{11}$

b. Offence

Book of the Law: Criminal offence stipulated in Article 489-569, Chapter I-IX wrote that Violation is "wetsdelicthten" i.e. deeds new legal nature can be experienced there is wet decisive after thus. ${ }^{12}$

In the results of interviews conducted with the head unit Pekon Community Development conference is a forum for counsel, deliberation and or agree to solve a problem both civil and criminal cases and that it could potentially lead to open conflict. According to the language, the word consultation means village consultation, to negotiate; talking, or representative of the group who disputes it was, find a peaceful resolution. Rembuk Pekon is a tradition in some areas in Indonesia and is often referred to by consensus in society Province of Lampung. ${ }^{13}$

In Article 4 of the Lampung Province Regional Regulation Number 1 of 2016 concerning Guidelines for Village and Village Discussion in Preventing Conflict in Lampung Province states that the Rembuk Pekon aims to:

\footnotetext{
${ }^{10}$ L. Mulyadi, "Mediasi Penal dalam Sistem Peradilan Pidana Indonesia: Pengkajian Asas, Norma, Teori dan Praktik", Yustisia, 2 No. 1, (2013): 114.https://doi.org/10.20961/yustisia.v2i1.11054.

${ }^{11}$ S. Soekanto, "Penanggulangan Kejahatan”, (Jakarta: Rajawali Pres, 1984), 44.

${ }^{12}$ Moeljatno, Asas - asas Hukum Pidana, (Jakarta: Rineka Cipta, 2003), 77.

${ }^{13}$ Erlina B, B. Hartono, Anggalana, M. Safitri, "Optimalisasi Nilai Kearifan Lokal Rembug Pekon dalam Pengelolaan Taman Hutan Raya (TAHURA) Wan Abdurahman Propinsi Lampung Sebagai Kawasan Hutan Konservasi Berbasis Masyarakat," Jurnal Keadilan Progresif 9, No. 2 (2018): 100-112.
} 
a. Accommodate the aspirations of rural and urban communities by the agreement in meetings together with the results of the deliberations to reach consensus;

b. Encourage initiative, the participation of the community to observe and resolve potential conflicts that exist in the villages and villages in order to prevent open conflict;

c. Improve the responsiveness of government implementing elements of villages and villages on the potential conflicts that exist in order to create a sense of security and peace; and

d. Improving the synergistic cooperation between implementing elements of village government and village community.

It was also stated that the Rembuk Pekon in its implementation is based on several principles, namely:

a. The guiding principle is that the implementation of the Pekon Rembuk must reflect the protection and respect for human rights and the dignity and dignity of each Indonesian citizen and population in proportion.

b. The principle of kinship is that the implementation of the Rembuk Pekon must reflect deliberation to reach consensus in every decision making.

c. The principle of humanity is that the implementation of the Rembuk Pekon should reflect the protection and respect for human rights and the dignity of every citizen and resident of Indonesia proportionally.

d. The principle of usefulness and efficacy is that the implementation of the Rembuk Pekon must be able to create order in society through the guarantee of legal certainty.

e. The principle of openness is that the implementation of Rembuk Pekon should involve communities in the whole process, from planning, financing, up to scrutiny.

f. The principle of balance, harmony and harmony is that the implementation of the Rembuk Pekon must consider the values that are alive and well respected in the community.

g. The principle of security and order is that the implementation of Rembuk Pekon should be carried out continuously and sustainably to create a safe atmosphere, serene and peaceful.

According to the Head of the Village Pahoman Bandar Lampung, currently, the existence of consultation Pekon is crucial to maintain security collectively in the consultation area. Pekon is in anticipation of the early rise of social conflicts that occur at lower levels such as in the village, pekon, villages and hamlets by prioritizing the completion conflict at the lower level and is expected to be an effort in the early of resolve the problems that often occur in the community.

According to the head of the police Criminal Investigation Unit of the resort city of Bandar Lampung, Indonesia still uses Criminal Code from the Netherland's legacy since colonialism as one of the sources of criminal law. 
Some Articles in the Criminal Code need to reviewed and modified in accordance with the condition of Indonesia and the current condition of society. Especially some of the provisions in the draft Criminal Code which deals with minor criminal offences such as minor or mild frauds and other acts that still cannot give a solution. In providing a sense of justice and public satisfaction with criminal law in Indonesia, especially the Criminal Code Act must be able to adjust to the times and society and conditions in Indonesia. The Supreme Court has made a regulation that regulates issues regarding cases involving minor crimes.

In the law, there is a change some of the provisions in the draft Criminal Code which deals with minor criminal offences, one of which is if there are acts of theft that injure someone below 2.500.000 IDR then such actions include minor criminal offences, which clearly regulated in the Indonesian Head of Supreme Court Regulation Number 2 of 2012 on the Misdemeanor Limitation and Amount of Fines in the Criminal Code. In these regulations, if a person is convicted of a misdemeanour, then who will prosecute the person only individual judges and subject to administrative penalties such as fines, compensation payments work in public services, and so on.

Furthermore, based on Article 205 paragraph (1) of the Criminal Code, said that the examination under interrogation minor criminal case is punishable by imprisonment or confinement for a minimum 3 (three) months or a fine of up to 7.500 IDR and mild punishment except those specified in paragraph 2.

Implementation of Rembuk Pekon in the context of settling criminal cases that not all types of criminal acts can be resolved by deliberation or there are only a few criminal acts that can be resolved, namely classified as minor criminal offences and criminal offences.

The types of criminal acts that can be resolved with the Rembuk Pekon are the types of criminal acts that are of a mild or harmless nature that meet the elements in Article 205 paragraph (1) of the Criminal Procedure Code, Attachment letter c, Indonesian Police Chief Regulation Number 3 of 2015 concerning Community police and the Republic of Indonesia Supreme Court Regulation Number 2 of 2012 concerning the Adjustment of Limits of Minor Crimes and the Number of Fines in the Criminal Code and criminal offences in the complaint offence category including Mild Animal Persecution (Article 302 paragraph (1) ); Minor insults (Article 315); Mild Abuse (Article 352 paragraph (1)); Minor Theft (Article 364); Light Darkening (Article 373); Minor Fraud (Article 379); Minor Damage (Article 407 paragraph 1); Minor retention (Article 482).

All the law was originally set up in a way, as they say, customary law, with a common language but not very precise, formed, that the customs and beliefs originally developed the law are common. Then by the jurisprudence 
of the court decision. Each society develops its common law because they have the language, customs (including trust) and a typical constitution.

Based on an analysis by the author can be seen that the type of crime that can be resolved by consultation Pekon this time is based on some of the new regulations Indonesian Head of Supreme Court Regulation Number 2 of 2012 on the Misdemeanor Limitation and Amount of Fines in the Criminal Code in the Book of the Law Legal Criminal and Attachment letter (c) Regulation of the Head of the Indonesian National Police Number 3 of 2015 concerning Community police which the previous regulation did not yet regulate, the law grows and develops together with the community.

Settlement of criminal acts through consultation in consensus or consensus has been widely applied in various regions, namely the people of Nanggroe Aceh Darussalam as Law Number 11 of 2006 concerning the Government of Aceh is implemented, and it is known that settlement of cases is done first through the Village Deliberation. Furthermore, in Balinese society, there are known traditional institutions in the form of Banjar, Subak, Pakraman village, Pakraman village assembly, and others who play a role in resolving adat cases. If a case occurs, the settlement is carried out in stages. Starting from the settlement at the internal family level, then to the Banjar level, if it fails at the custom village level (Pakraman village). Then if it fails, the case continues to the Pakraman assembly-level through mediation (Majit alit village Pakraman), then to the level of Sabha Kertha (traditional justice by the Pakraman village Madya council) and the level of appeal by the Pakraman village main assembly. In Pakraman traditional villages, a wig-a wig is applied, which is another dimension identical to the settlement of cases outside the court through the mediation of penalties. Then in West Nusa Tenggara (Lombok), especially in the Sasak tribe, there are known ways of solving problems (cases) through deliberations (Begundem) to achieve peace. ${ }^{14}$

\section{Procedure for Settling Crime of Theft through Pekon, Discussion Process based on Regulation of the Head of Indonesian National Police Number 3 of 2015 concerning Community Police}

Restorative Justice said as a basic guideline in achieving justice made by the parties outside the court for a peace process of criminal and victim are the occurrence of consequences, namely the loss of the victim or the criminal act. ${ }^{15}$ That the process of Rembuk Pekon brings perpetrators and victims sit together to find the best solution, in the presence of the perpetrator, the victim, the family, the village government, Bhayangkara Public Order and Safety

\footnotetext{
${ }^{14}$ Yusriando, "Implementasi Mediasi Penal Sebagai Perwujudan Nilai-Nilai Pancasila Guna Mendukung Supremasi Hukum dalam Rangka Pembangunan Nasional," Jurnal Pembaharuan Hukum 2, No. 1 (2018): 23-45.http://dx.doi.org/10.26532/jph.v2i1.1413.

15 J. Braithwaite, "Restorative Justice and Responsive Regulation,"The Australian and New Zealand Journal of Criminology 36, No. 1 (2002): 109-126.
} 
Trustees, village-level noncommissioned and community leaders. The existence of the meeting is expected to recover pain and loss suffered by victims, by the perpetrators to provide compensation, or do social work, make improvements or certain activities in accordance with a joint decision has been agreed.

Rembuk Pekon in solving a problem of crime is a form of legal reforms that aim to make the laws be flexible in finding the solution outside the prison as the completion of a crime. It also aims for the improvement of the victim's loss and self-improvement for the criminal. The criminal policy cannot be separated from the broad policy, namely social policy which consists of policies/measures to social welfare policy and policies/ measures for the protection of society (common defence policy). ${ }^{16}$ In the end, the criminal law policy is also part of the social development policy to address crime through criminal law is an integral part of the protection of the business community and the welfare of society. ${ }^{17}$

According to G. P Hoefnagels cited by Barda Nawawi Arief crime prevention efforts can be reached at:

a. The application of criminal law (criminal law application)

b. Prevention without crime (prevention without punishment)

c. Influencing the community perceptions of crime and conviction through mass media (Influencing views of society, crime and punishment/mass media). ${ }^{18}$

Crime prevention with the use of criminal law is part of a criminal policy. The crime prevention is to achieve the ultimate goal of the criminal policy itself, which protects the public to achieve prosperity for the community. One of the efforts to prevent and control crime problem is to use the criminal law. Thus the crime prevention efforts broadly divided into two, namely:

a. Penal Efforts (Criminal Law)

Efforts were more focused on the repressive nature (suppression or eradication or crushing) of the crime. It is equivalent to applying the criminal law (criminal law application) true. ${ }^{19}$

b. Efforts Non-Penal (Criminal Law Outside)

\footnotetext{
${ }^{16}$ J. Kusuma, "Kebijakan Hukum Pidana dalam Upaya Penanggulangan Tindak Pidana Melalui Penyelesaian diluar Proses", Sol Justicia, 2 No. 1, (2019): 21-35. http://ojs.ukb.ac.id/index.php/sj/article/view/50.

${ }^{17}$ Muhaimin, "Restoratif Justice dalam Penyelesaian Tindak Pidana Ringan", Jurnal Penelitian Hukum De Jure, 19 No. 2, (2019): 185-206. http://dx.doi.org/10.30641/dejure.2019.V19.185206.

${ }^{18}$ B. Nawawi, Arief, Masalah Penegakan Hukum dan Kebijakan Penanggulangan Kejahatan, (Bandung: Citra Aditya Bakti, 2001), 73.

19 Z. O. Jainah, "Membangun Budaya Hukum Masyarakat Penegak Hukum Dalam Pembarantasan Tindak Pidana Narkotika," Jurnal Keadilan Progresif 2, No. 2 (2011): 123136.
} 
Efforts were more focused on preventive nature (prevention/deterrence) before the occurrence of the crime. It is meant to prevent crime through measures that are considered relevant. ${ }^{20}$

The criminal law policy action in relation to the following matters:

a. How does the government's efforts to tackle crime with criminal law?

b. How do we formulate criminal law to conform to the conditions of the community?

c. How can a government policy regulate society by criminal law?

d. How to use the criminal law to regulate society in order to achieve a larger goal? $?^{21}$

Furthermore, in the process of Rembuk Pekon there are several parties to be heard information or opinions such as:

a. The victim in the Rembuk Pekon settlement is very important. It is because so far in the criminal justice system, the victim is less involved in the conflict. In the deliberative Rembuk Pekon important voices or interests of victims to be heard and a part of the decision to be taken.

b. Actors and family parties. The perpetrator is an absolute party involved and in view of the perpetrator's family needs to be involved more caused because of the age of the perpetrators who are minors (children). Involvement also in view of the perpetrator's family is very important because the family is very likely to be part of the settlement agreement as in the case of compensation payments or other compensation implementation.

c. Community representative. Community representatives are important to represent the interests of the environment in which the criminal act occurred. The goal is that the interests of the public are expected to still be represented in decision making. The criteria for community representatives are community leaders or parties who are considered local community leaders (have legitimacy as representatives of the people), has no interest in the case at hand (can act independently). Noting that gender balance is always represented the aspirations of women in decision-making.

The crime of theft resolution procedure through Rembuk Pekon by Indonesian National Police Chief Regulation Number 3 of 2015 on the Community Police done in several stages of which can be described as follows:

a. Recording Report/Public Complaints

\footnotetext{
${ }^{20}$ H. Djanggih, "Konsepsi Perlindungan Hukum Bagi Anak sebagai Korban Kejahatan Siber Melalui Pendekatan Penal dan Non Penal," Mimbar Hukum 30, No. 2 (2018): 316-330. https://doi.org/10.22146/jmh.32017.

21 K. Irsan, "Arah Politik Hukum Pidana dalam Rencana Undang-Undang Hukum Pidana,"Jurnal Keamanan Nasional 1, No. 1 (2015):80-104. http://dx.doi.org/10.31599/jkn.v1i1.14.
} 
Implementation Rembuk Pekon begins with the reports received by members Bhayangkara Public Order and Security Supervisor (Bhabinkamtibmas) of the community or the victims. Then members keep records on the report.

b. Going to the place Genesis Case

Furthermore, that member Bhabinkamtibmas together with the people went to the crime scene for later examination of the scene to collect evidence of the victim.

c. Request information from victims, witnesses, and other concerned parties about cases that took place that in this case, the member Bhabinkamtibmas dialogue to witnesses, victims and also by some parties testify for more evident perspectives.

d. Preparation for Rembuk Pekon

Furthermore, in the process of Rembuk Pekon, member of Bhabinkamtibmas determine the place and time of the meeting with the two sides being litigants and also brought some of the parties in the deliberations.

e. Implementation of Rembuk Pekon Meeting

Then the following activities are conducted meetings with both sides on the schedule that has been set.

f. Deliberation Process

The next activity the deliberative process involving both parties, either victims or perpetrators, then Bhabinkamtibmas members and village officials heard testimony from both sides both victims and perpetrators.

g. Provide opinions and suggestions

Whereas furthermore member Bhabinkamtibmas and participants give their views, feedback, opinions, suggestions to both parties to the settlement, the settlement of the criminal case of theft that should be resolved by consensus. This is because in the view of the mediator that both sides have agreed to make peace, and his actions are still classified as misdemeanours.

h. Peaceful Settlement

In the process of Rembuk Pekon in resolving cases, both parties agreed to settle with the family and make a note of peace.

i. Make a Letter of Agreement

After the peace agreement between both parties then the next stage is to make the letter a common agreement on the settlement which was later made and signed by the victim and the offender then Bhayangkara witnesses and members of the Bhayangkara Public Order and Security Supervisor. Once created and signed a letter of agreement that the criminal offence of theft have been completed.

Therefore, the law or regulation functions to change the mindset of the people to be obedient to the law. This is in accordance with the issuance of 
several laws and regulations concerning the Rembuk Pekon including the Regional Regulation of Lampung Province Number 1 of 2016 concerning Guidelines for Village and Village Discussion in Preventing Conflict in Lampung Province and also the Police Regulation Number 3 of 2015 on community police, based on this it can be seen that the procedures for the settlement of the crime of theft through Rembuk Pekon done in several stages such as: Noting the reports/complaints from the public, Come to the crime scene Requesting information to victims, witnesses, and other related parties regarding the case that occurred, Conducting preparations for Rembuk Pekon, Conducting Pekon Discussion activities, Deliberation Process, Providing opinions and suggestions, Peace Process, Making Joint Agreement Letter.

\section{The Result of the Settlement Law Crime of Theft Through Rembuk Pekon}

The settlement of criminal cases is generally settled through the criminal justice system or also known as the Criminal Justice System. The criminal justice system starts from investigations by the police, indictments by prosecutors, decisions by judges in the Pre-Judicial Process, which ends in prison. Criminal Justice System, regulated in the Criminal Procedure Code. ${ }^{22}$ The Criminal Procedure Code is a formal law governing criminal material laws that are regulated in the Criminal Code. The purpose of the criminal justice system is to be able to resolve criminal cases that occur so that the community is satisfied that justice has been upheld and the guilty person is convicted. Strictly the Criminal Justice System in the Criminal Procedure Code aims to obtain material truth. The settlement of criminal cases using a repressive approach as implemented in the Criminal Justice System has given birth to retributive justice, which is oriented to retaliation in the form of punishment and imprisonment that the implementation of retributive justice is deemed insufficient to produce justice for all parties, especially victims. ${ }^{23}$

Besides the criminal justice system related to the police, prosecutors, courts, social institutions is an integrated system called the "criminal justice system", which is implemented as an effort to tackle crime in the community. However, this system has not been fully implemented because in reality, the crime rate is increasingly increased, and there are still many perpetrators of crime who turned out to commit more crimes or recidivists. To overcome weaknesses in the system that emphasizes retributive passive perpetrators and victims of crime, it is by the emergence of restorative justice. Restoration of

\footnotetext{
${ }^{22}$ R. E. Al Amin Siregar, "Due Process of Law dalam Sistem Peradilan Pidana di Indonesia Kaitannya dengan Perlindungan HAM," FITRAH 1, No. 1 (2015): 35-46. https://doi.org/10.24952/fitrah.v1i1.326.

${ }^{23}$ T. M. Sirait, "The Implementation of Procedural Law of Responsibility Enforcement of Corporate Crime in Integral Criminal Justice System," Jurnal Dinamika Hukum 17, No. 3 (2017): 343-349. http://dx.doi.org/10.20884/1.jdh.2017.17.3.769.
} 
Restorative Justice views victims and perpetrators of criminal acts are allowed to resolve conflicts and recover damages caused and let perpetrators of criminal acts to be directly responsible for their actions. The purpose of restorative justice is to empower victims, perpetrators, families, and the community to improve an act against the law by using awareness and conviction as a basis for improving people's lives.

Rembuk Pekon is one of restorative justice which in principle is a way to settle disputes outside the court through negotiations involving third parties that are neutral (non-intervention) and impartial (impartial) and is accepted by the parties to the dispute. A third party, called a mediator or mediator, has the task of assisting the parties to the dispute in solving the problem but does not have the authority to make decisions. In the Rembuk Pekon, a mediator has the role of helping the parties to the dispute by identifying the disputed problem, developing choices, and considering alternatives that can be offered to the parties to reach an agreement. The mediator in carrying out his role only has the authority to provide advice or determine the process of the Rembuk Pekon in seeking dispute resolution. The mediator does not have the authority and decisive role to the content of the dispute, and only safeguards how the Rembuk Pekon process can proceed, thus resulting in an agreement from the parties.

As a result of the legal settlement of the crime of theft through Rembuk Pekon that case is to be completed without any claim to the criminal justice process, it is caused due to an agreement between the two sides to make peace and has made a letter of mutual agreement signed by both of them as well as possible witnesses. The contents of the collective agreement such letter consists of The identity of the victim and perpetrator; The contents of the statement is done without any pressure either determined and entered the collective agreement such as: an apology from one of the parties or to forgive each other from both sides, the ability to recover damages from one of the parties, promise not to repeat his actions, will not sue each other, etc. Their signature of both parties, then some village or community representatives as well as members Bhayangkara Public Order and Security Supervisor.

That with the Rembuk Pekon that promote consultation between the victim and the offender will promote justice for both parties. Legal certainty will also be created to be made, and the signing of a letter of agreement for peace between the two sides and benefits law will also be created along with peace of the parties to mutual forgiveness and for the perpetrators of criminal acts can be responsible for losses suffered by the victim and not repeat his actions again. Based on this it can be seen that the purpose of the law is to promote justice, certainty and expediency, therefore, due to the legal settlement of theft through Rembuk Pekon without a criminal justice process this with the proven existence of a letter of agreement jointly signed by the parties as a sign has agreed to terms. 


\section{Conclusion}

Based on the results of the discussion, it can be concluded that the types of criminal acts that can be resolved with the Rembuk Pekon include minor criminal offences Article 302 (regarding minor maltreatment of animals), Article 352 paragraph (1) (minor maltreatment), Article 364 (theft minor), Article 373 (minor embezzlement), Article 379 (minor fraud), Article 482 (minor detention), and Article 315 (mild humiliation), Minor damage (Article 407 paragraph 1), and criminal offence of complaint Article 284.

The crime of theft resolution procedure through Rembuk Pekon by Indonesian National Police Chief Regulation Number 3 of 2015 on Community police is done by several stages, including Preparing for Rembuk Pekon; Rembuk Pekon activities; Deliberation Process; Give opinions and suggestions; Peace Process; Make a Letter of Agreement.

As a result of the legal settlement of the crime of theft through Rembuk Pekon that the case has been declared over by not proceed to the criminal justice process, it is evidenced by the existence of a collective agreement signed by the parties as a sign already agreed to terms and known by Bhayangkara Trustees of Security and Order community, the Village Head, community Leaders, Indigenous People and the Police and Community Partnership Forum.

Suggestions are towards in the implementation of the Rembuk Pekon for the police, in this case, Bhayangkara Public Order and Security Supervisor should carry out the Rembuk Pekon to prioritize professional, modern and reliable principles, this so that the implementation of the Rembuk Pekon can run optimally. The need for an increase in efforts to settle the offence by the Rembuk Pekon process as local culture and local policy by government, law enforcement officers and the public to bring about justice and reduce conflict in society, as well as an increase in cooperation between police and government officials Province of Lampung, to uncover other cases can be run properly and in accordance with procedures and can enhance guidance to the public the importance of the law's interests. 


\section{References}

Al Amin Siregar, R. E. “Due Process of Law dalam Sistem Peradilan Pidana di Indonesia Kaitannya dengan Perlindungan HAM." FITRAH 1, No. 1 (2015): 35-46. https://doi.org/10.24952/fitrah.v1i1.326.

B. Erlina, Hartono B., Anggalana, Safitri M. "Optimalisasi Nilai Kearifan Lokal Rembug Pekon dalam Pengelolaan Taman Hutan Raya (TAHURA) Wan Abdurahman Propinsi Lampung Sebagai Kawasan Hutan Konservasi Berbasis Masyarakat.” Jurnal Keadilan Progresif 9, No. 2 (2018): 100-112.

Braithwaite, J. "Restorative Justice and Responsive Regulation", The Australian and New Zealand Journal of Criminology 36, No. 1 (2002): 109-126.

Djanggih, H. "Konsepsi Perlindungan Hukum Bagi Anak sebagai Korban Kejahatan Siber Melalui Pendekatan Penal dan Non Penal." Mimbar Hukum 30, No. 2 (2018): 316-330.https://doi.org/10.22146/jmh.32017.

Irsan, K. "Arah Politik Hukum Pidana dalam Rencana Undang-Undang Hukum Pidana." Jurnal Keamanan Nasional 1, No. 1 (2015): 80-104. http://dx.doi.org/10.31599/jkn.v1i1.14.

Jainah, Z. O. "Membangun Budaya Hukum Masyarakat Penegak Hukum Dalam Pembarantasan Tindak Pidana Narkotika", Jurnal Keadilan Progresif 2, No. 2 (2011): 123-136.

Kusuma, J. "Kebijakan Hukum Pidana dalam Upaya Penanggulangan Tindak Pidana Melalui Penyelesaian diluar Proses," Sol Justicia 2, No. 1 (2019): 21-35. http://ojs.ukb.ac.id/index.php/sj/article/view/50.

Lampung Province Regional Regulation Number 1 Year of 2016 concerning Guidelines for Village and Village Discussion in Preventing Conflict in Lampung Province.

M. Ridwan. Mediasi Penal Terhadap Perkara KDRT (Kekerasan Dalam Rumah Tangga), Jakarta: Yayasan Gema Yustisia Indonesia, 2010.

Muhaimin."Restoratif Justice dalam Penyelesaian Tindak Pidana Ringan."

Jurnal Penelitian Hukum De Jure 19, No. 2 (2019): 185-206. http://dx.doi.org/10.30641/dejure.2019.V19.185-206.

Mulyadi, L. "Mediasi Penal dalam Sistem Peradilan Pidana Indonesia: Pengkajian Asas, Norma, Teori dan Praktik." Yustisia 2, No. 1 (2013): 114. https://doi.org/10.20961/yustisia.v2i1.11054.

Moeljatno. Asas - Asas Hukum Pidana. Jakarta: Rineka Cipta,2003.

Nawawi, B. Arief. Masalah Penegakan Hukum dan Kebijakan Penanggulangan Kejahatan. Bandung: Citra Aditya Bakti, 2001.

Okamahendra, N. "Eksistensi Peraturan Mahkamah Agung No. 02 Tahun 2012 tentang Penyesuaian Batasan Tindak Pidana Ringan dan Jumlah Denda dalam KUHP.” JATISWARA Jurnal Ilmu Hukum 32, No. 1 (2017): 110-119. https://doi.org/10.29303/jatiswara.v32i1.74. 
P. Teguh and H. B. Abdul. Politik Hukum Pidana - Kajian Kebijakan Kriminalisasi dan Dekriminalisasi. Jakarta: Pustaka Pelajar, 2005.

Republic of Indonesia Supreme Court Regulation Number 02 Year of 2012 concerning Adjustment of Limits of Minor Crimes and the Amount of Fines in the Criminal Code.

S. Soerjono. Penanggulangan Kejahatan. Jakarta: Rajawali Pres, 1984.

S. Soerjono., M. Sri. Penelitian Hukum Normatif, Suatu Tinjauan Singkat. Jakarta: Raja Grafindo Persada, 2011.

Suhariyanto, B. "Progresivitas Putusan Pemidanaan Terhadap Pelaku Tindak Pidana Korupsi."Jurnal Penelitian De Jure 16, No. 2 (2016): 201-213. http://dx.doi.org/10.30641/dejure.2016.V16.201-213.

Surya, F. A. "Tinjauan Mediasi Penal Perspektif Hukum Adat dan Hukum Islam." Jurisprudence 5, No. 2 (2015): 118-126. https://doi.org/10.23917/jurisprudence.v5i2.4229.

Simanjuntak, N. "Penguatan Lembaga Adat Sebagai Alternatif Penyelesaian Sengketa." Negara Hukum 4, No. 1 (2013): 36-66. https://doi.org/10.22212/jnh.v4i1.195.

Sirait, T. M. "The Implementation of Procedural Law of Responsibility Enforcement of Corporate Crime in Integral Criminal Justice System." Jurnal Dinamika Hukum 17, No. 3 (2017): 343-349. http://dx.doi.org/10.20884/1.jdh.2017.17.3.769.

Thalib, H., Ramadhan, A., Djanggih, H. "The Corruption Investigation in the Regional Police of Riau Island, Indonesia." Rechtsidee 4, No. 1 (2017): 71-86. https://doi.org/10.21070/jihr.v4i1.988.

Act Number 1 of 1946 concerning the Imposition of the Indonesian Criminal Code (KUHP).

Act Number 8 of 1981 concerning the Criminal Procedure Law (KUHAP).

Act Number 30 of 1999 concerning Arbitration and Alternative Dispute Resolution.

The Act Number 2 of 2002 concerning the Indonesian National Police.

Yusriando. "Implementasi Mediasi Penal Sebagai Perwujudan Nilai-Nilai Pancasila Guna Mendukung Supremasi Hukum dalam Rangka Pembangunan Nasional." Jurnal Pembaharuan Hukum 2, No. 1 (2018) : 23-45. http://dx.doi.org/10.26532/jph.v2i1.1413.

Zaini, Z. D. "Lembaga Mediasi Perbankan Sebagai Alternatif Penyelesaian Sengketa Perbankan di Indonesia." Jurnal Keadilan Progresif 3, No. 1 (2012): 1-20. 